\title{
Gastrin/cholecystokinin Type B Receptor Inhibitor Z-360
}

National Cancer Institute

\section{Source}

National Cancer Institute. Gastrin/cholecystokinin Type B Receptor Inhibitor Z-360. NCI

Thesaurus. Code C61329.

A selective, orally available, 1,5-benzodiazepine-derivative gastrin/cholecystokinin 2 (CCK-

2) receptor antagonist with potential antineoplastic activity. Z-360 binds to the gastrin/CCK-2 receptor, thereby preventing receptor activation by gastrin, a peptide hormone frequently associated with the proliferation of gastrointestinal and pancreatic tumor cells. 